\title{
Decreased Stimulated GM-CSF Production and GM-CSF Gene Expression but Normal Numbers of GM-CSF Receptors in Human Term Newborns Compared with Adults ${ }^{1}$
}

\author{
MITCHELL S. CAIRO, YU SUEN, EVA KNOPPEL, CARMELLA VAN DE VEN, ANNA NGUYEN, \\ AND LEONARD SENDER \\ Division of Hematology/Oncology, Children's Hospital of Orange County, Orange. California 92668 and \\ Division of Research Immunology and Bone Marrow Transplantation, Childrens Hospital Los Angeles, \\ Los Angeles, California 90054
}

\begin{abstract}
We investigated cord and adult production of granulocyte-macrophage colony-stimulating factor (GM-CSF), expression of GM-CSF mRNA from unstimulated and activated mononuclear cells, and the affinity and presence of GM-CSF receptors on mature effector cells in an attempt to better understand the underlying pathophysiology of altered neonatal host defense. Utilizing ${ }_{125}$ I-GM-CSF as a ligand, Scatchard analysis revealed the presence of a single class affinity GM-CSF receptor with similar binding characteristics on both cord and adult peripheral PMN ( $k_{d}=44$ and $\left.39 \mathrm{pM}\right)$ for adult and cord, respectively. Additionally, there was no significant difference in the number of GM-CSF receptors on cord versus adult neutrophils. Using a sandwich ELISA for measuring GM-CSF levels, we found nondetectable levels from supernatants of unstimulated cord and adult mononuclear cells and serum from cord and adult peripheral blood. However, there was a significant difference between cord and adult GM-CSF production from stimulated phytohemagglutinin and phorbol-12-myristate-6-acetate mononuclear cells $(p<0.02)$. Additionally, GM-CSF mRNA expression from activated cord mononuclear cells was significantly reduced after $6 \mathrm{~h}$ of stimulation compared with adults. Nuclear run-on experiments revealed no difference in transcriptional activation from activated cord and adult mononuclear cells. Actinomycin D transcriptional decay studies, however, demonstrated reduced GM-CSF half-life from activated cord versus adult mononuclear cells $\left(t_{1 / 2} 30\right.$ versus $100 \mathrm{~min}$ ). These results suggest normal affinity and numbers of GM-CSF receptors on peripheral mature effector cells but decreased GM-CSF production and GMCSF mRNA expression from activated cord versus adult mononuclear cells. Reduced GM-CSF mRNA expression and production may explain in part the difference in host defense between the newborn and the adult during states of increased demand. (Pediatr Res 30: 362-367, 1991)
\end{abstract}

\section{Abbreviations}

GM-CSF, granulocyte-macrophage colony-stimulating factor

Received January 21, 1991; accepted June 5, 1991

Correspondence and reprint requests: Mitchell S. Cairo, M.D., Director, Hematology/Oncology Research and Bone Marrow Transplantation, Children's Hospital of Orange County, 455 S. Main Street, Orange, CA 92668.

Supported by grants from the Pediatric Cancer Research Foundation, the Walden W. and Jean Young Shaw Foundation, and the CHOC Research and Education Fund.

${ }^{1}$ Presented in part at the Society of Pediatric Research, May 1990, in Anaheim. CA.
CFU-GM, colony forming unit granulocyte-macrophage CSF, colony-stimulating factor

MNC, mononuclear cell

PMN, polymorphonuclear cell

PMA, phorbol-12-myristate-6-acetate

PHA, phytohemagglutinin

rh, recombinant human

Hematopoiesis in the preterm and term newborn is developmentally immature compared with the adult (1). Specific differences in myelopoiesis have been demonstrated in term newborn rats compared with adult animals. Reduced neonatal rat myeloid progenitor pools, accelerated myeloid progenitor proliferative rates, and decreased total body neutrophil storage pools all predispose the newborn rat to depletion of mature effector neutrophils and a tendency to develop neutropenia during states of increased demand or overwhelming bacterial sepsis (2-4). During experimental sepsis (states of increased demand), adult animals increase their CFU-GM pool two to three times greater than baseline and increase their proliferative rate to approximately $75 \%$ of maximal capacity. In contrast, however, term newborns under the same conditions decrease their already reduced CFUGM pool by almost $50 \%$ and fail to increase their already maximal proliferative myeloid pool, remaining at $75-80 \%$ of capacity $(5,6)$. Additionally and most importantly, neonatal rats also deplete their already reduced neutrophil storage pool reserves by almost $80-90 \%$, compared with a decline of only $25-33 \%$ in adult rats $(6,7)$.

Recently, it has been demonstrated that cellular proliferation, maturation, and differentiation of hematopoietic progenitor cells and the regulation of hematopoiesis are dependent in part on the continuous and/or intermittent supply of highly specific hematopoietic growth factors (CSF) (8-11). CSF stimulate proliferation of bone marrow myeloid progenitor cells, induce the release of mature effector neutrophil storage pools, and enhance mature neutrophil effector function. CSF may, in fact, be the major regulator of increased myeloid cell production during states of increased demand. GM-CSF, first purified to homogeneity from a medium conditioned by a human $T$ lymphotrophic virus (HTLV II)-infected T lymphoblastoid cell line (MO), is one such CSF that stimulates the formation of granulocyte, macrophage, and eosinophil colonies in human bone marrow cell culture $(12,13)$. GM-CSF additionally primes adult neutrophils for enhanced oxidative metabolism, chemotaxis, and phagocytosis; induces expression of surface active adhesion glycoproteins such as $\mathrm{C} 2 \mathrm{bi}$; and enhances antibody-dependent cytotoxicity 
(14-18). GM-CSF has recently been utilized as adjuvant therapy in the treatment of a number of clinical conditions including aplastic anemia, AIDS, bone marrow transplantation, and myelodysplasia (19)

Recently, we have demonstrated that rhGM-CSF primes neonatal granulocytes for enhanced oxidative metabolism, chemotaxis, bacterial killing, C3bi expression, and adherence $(20,21)$. Murine GM-CSF has also been noted to enhance neonatal rat myelopoiesis and have some protective activity against bacterial infection in the newborn rat $(22,23)$. In an attempt to understand the differences in host defense between the newborn and the adult and the potential usefulness of exogenous GM-CSF administration in the neonatal period, we investigated the constitutive and stimulated production of GM-CSF from adult and newborn MNC, expression of GM-CSF mRNA under similar conditions, and the affinity and number of GM-CSF receptors on mature neonatal and adult neutrophil effector cells.

\section{MATERIALS AND METHODS}

Isolation of human PMN and MNC. Heparinized venous blood was drawn from normal volunteers in accordance with the principles of the Declaration of Helsinki. Venous cord blood was drawn from the umbilical vessels of placentas of normal, fullterm, nonstressed infants immediately after vaginal delivery or scheduled cesarean section. Adult or cord red blood cells and neutrophils were allowed to sediment after the addition of $6 \%$ Dextran-70 in $0.9 \%$ saline (Baxter Laboratories, Irvine, CA). The leukocyte-enriched plasma was collected, layered on a FicollHypaque gradient (density $=1.077$ ) (Sigma Chemical Co., St. Louis, MO), and centrifuged for $30 \mathrm{~min}$. PMN were recovered in the cell pellet, and any remaining erythrocytes were hemolyzed by hypotonic lysis. MNC were recovered in the liquid interface and were then suspended for culture in RPMI 1640 (Gibco, Grand Island, NY) with $10 \%$ human AB serum (Sigma), glutamine, and penicillin/streptomycin. PMN and MNC isolated by this density gradient separation were purified to greater than $98 \%$ homogeneity, and cell viability as measured by trypan blue exclusion was more than $99 \%$ (adult: $86 \pm 4.0 \%$ lymphocytes and $7.2 \pm 3.0 \%$ monocytes; cord: $82 \pm 8.0 \%$ lymphocytes and $8.8 \pm 4.0 \%$ monocytes).

PMN were used in the following assays within $2 \mathrm{~h}$ of collection. MNC $\left(1.0 \times 10^{6}\right.$ cells $\left./ \mathrm{mL}\right)$ were stimulated in culture with PMA (Sigma) $(20 \mathrm{ng} / \mathrm{mL})$, and PHA $(2 \mu \mathrm{g} / \mathrm{mL})$ (Gibco). Supernatants were harvested at 24-72 $\mathrm{h}$ and assayed for GM-CSF levels.

Binding of iodinated GM-CSF to neutrophils. Isolated neutrophils were suspended in a binding medium of Iscove's modified Dulbecco's medium (Gibco) with $25 \mathrm{mM} \mathrm{N}$-2-hydroxyethylpiperazine- $N^{\prime}$-2-ethanesulfonic acid, and BSA (2 mg/mL) (pH 7.4). Cells $\left(4 \times 10^{6}\right)$ were suspended in binding medium containing various concentrations of ${ }^{125}$ I-labeled GM-CSF (DuPont/New England Nuclear), with or without a 100 -fold excess of unlabeled $\mathrm{GM}-\mathrm{CSF}$, and incubated for $2 \mathrm{~h}$ at $23^{\circ} \mathrm{C}$. After incubation, the cells were resuspended and transferred onto an ice-cold mixture of $75 \%$ FCS in a binding medium (24). The cells were centrifuged for $2 \mathrm{~min}$, supernatant was aspirated, and the radioactivity of the pellets was counted in an LKB universal gamma counter (Pharmacia, Milwaukee, WI). Specific binding was defined as the amount of binding blocked by competition with a 100-fold excess unlabeled GM-CSF. Data was analyzed by weighted nonlinear least squares curve-fitting developed by Munson and Rodbard (25).

GM-CSF levels. GM-CSF concentrations from MNC culture supernatants and healthy donor serum samples were measured by a sandwich ELISA adopted from Cebon et al. (26). Microtiter plates were coated with the mouse antihuman GM-CSF MAb (Genzyme, Boston, MA) $(200 \mathrm{ng} / 40 \mu \mathrm{L})$ in PBS $\left(16 \mathrm{~h}\right.$ at $\left.20^{\circ} \mathrm{C}\right)$ and then blocked with PBS with $1 \%$ (wt/vol) BSA (Sigma) for 6 $\mathrm{h}$ at $20^{\circ} \mathrm{C}$. The plates were rinsed with water, blotted dry, and stored at $-20^{\circ} \mathrm{C}$ until use. After the plates were thawed, a 150 $\mu \mathrm{L}$ sample was incubated at $4^{\circ} \mathrm{C}$ for $16 \mathrm{~h}$. The plates were then washed with washing buffer (PBS with $0.1 \% \mathrm{vol} / \mathrm{vol}$ Tween 20 ). Rabbit antihuman GM-CSF polyclonal antibody (Genzyme) was diluted 1:1500 in EDB (PBS with $0.2 \%$ Tween $20 \mathrm{vol} / \mathrm{vol}$ and $0.1 \% \mathrm{BSA} w \mathrm{wt} / \mathrm{vol}$ ) and incubated for $3 \mathrm{~h}$ at $20^{\circ} \mathrm{C}$. Bound rabbit antibody was detected using biotinylated antirabbit Ig from donkey (Amersham, Chicago, IL) at 1:500 vol/vol in EDB. After washing the plates, streptavidin-biotinylated horseradish peroxidase complex (Amersham) diluted 1:1000 in EDB was incubated for $15 \mathrm{~min}$. Finally, $150 \mu \mathrm{L}$ of 3, 3', 5, 5'-tetramethylbenzidine solution with hydrogen peroxide (TMB Peroxidase EIA kit; BioRad Laboratories, Richmond, CA) were added and the reaction was stopped at $30 \mathrm{~min}$ with $1 \mathrm{~N} \mathrm{H}_{2} \mathrm{SO}_{4}$. Optical density was measured at $450 \mathrm{~nm}$ with Bio-Rad ElA reader. RhGM-CSF (Amgen, Thousand Oaks, CA) was used as the standard for the ELISA $(5 \mathrm{pg} / \mathrm{mL}$ to $50 \mathrm{ng} / \mathrm{mL}$ ). Patient serum samples were diluted with PBS $1 \%$ BSA wt/vol before analysis and rhGM-CSF levels were determined using a standard curve of predetermined concentrations of rhGM-CSF in human serum.

$R N A$ isolation and Northern blotting. Total RNA was extracted as previously described by Chomczynski $\mathrm{ct}$ al. (27) and electrophoresed on a $1 \%$ agarose. $5 \%$ formaldehyde gel. The samples were heated in $40 \%$ formamide, $14 \%$ formaldehyde at $65^{\circ} \mathrm{C}$ for $15 \mathrm{~min}$ and then cooled. To ensure that an equal amount of RNA was loaded in each lane, $1 \mu \mathrm{g}$ ethidium bromide was added to each sample before loading. RNA was transferred to nitrocellulose and baked $2 \mathrm{~h}$. Hybridization was done at $42^{\circ} \mathrm{C}$ in $50 \%$ formamide, $5 \times$ sodium chloride, sodium citrate (SSC), $1 \times$ Denhardt's, 50 mM sodium phosphate (pH 6.5), 0.1\% SDS, 250 $\mu \mathrm{g} / \mathrm{mL}$ salmon sperm DNA, and $10 \%$ dextran sulfate and probed with ${ }^{32} \mathrm{P}$-labeled GM-CSF cDNA (B1H1 from ATCC). Filters were washed to a stringency of $0.3 \times$ SSC at $65^{\circ} \mathrm{C}$ and exposed to Kodak XAR-5 film.

Nuclear run-on transcription assays. A total of $10^{8} \mathrm{MNC}$ were stimulated for $6 \mathrm{~h}$ with PMA $20 \mathrm{ng} / \mathrm{mL}$, PHA $2 \mu \mathrm{g} / \mathrm{mL}$. Nuclei isolation and nuclear run-ons were done using slight modifications of previously described techniques (28). The cells were washed in PBS, lysed in $4 \mathrm{~mL}$ lysis buffer [ $10 \mathrm{mM}$ Tris ( $\mathrm{pH} 7.4)$, $10 \mathrm{mM} \mathrm{NaCl}, 3 \mathrm{mM} \mathrm{MgCl}, 0.5 \% \mathrm{NP}-40]$ on ice for $5 \mathrm{~min}$, and centrifuged for $5 \mathrm{~min}$ at $1500 \mathrm{rpm}\left(4^{\circ} \mathrm{C}\right)$ in a Beckman TJ-6 centrifuge to pellet the nuclei. The nuclei were washed in lysis buffer, then resuspended in $100 \mu \mathrm{L}$ storage buffer ( $40 \%$ glycerol, $50 \mathrm{mM}$ Tris, $5 \mathrm{mM} \mathrm{MgCl}_{2}, 0.1 \mathrm{mM}$ EDTA) and kept at $-70^{\circ} \mathrm{C}$ until use. To label the nuclear RNA, $50 \mu \mathrm{L}$ of elongation mix [20 mM Tris (pH 8.0), $10 \mathrm{mM} \mathrm{MgCl} 2,100 \mathrm{mM} \mathrm{KCl}, 10 \mathrm{mM}$ DTT]; $5 \mu \mathrm{L}$ each of $10 \mathrm{mM}$ ATP, guanosine triphosphate, and cytidine triphosphate; $5 \mu \mathrm{L}$ RNAsin (Promega, Madison, WI); $20 \mu \mathrm{L}$.2 P-uridine triphosphate (Amersham; $3000 \mathrm{Ci} / \mathrm{mmol}$ ); and $25 \mu \mathrm{L} \mathrm{H} \mathrm{H}_{2} \mathrm{O}$ were added to the nuclei and heated at $30^{\circ} \mathrm{C}$ for 30 min. The reaction was terminated by the addition of 40 IU RNase-free DNase and further incubated at $30^{\circ} \mathrm{C}$ for $10 \mathrm{~min}$. Ten microliters of stop buffer [ $10 \%$ Sarcocyl, 100 mM EDTA, $100 \mathrm{mM}$ Tris (pH 7.6), $1 \mathrm{mg} / \mathrm{mL}$ Proteinase $\mathrm{K}$ ] were added and heated at $40^{\circ} \mathrm{C}$ for 30 min. Fifteen microliters yeast transfer RNA was added as carrier, followed by three phenol/chloroform/ isoamyl extractions, and precipitated with ethanol. Four micrograms of linearized denatured single-stranded plasmid DNA was loaded per well onto nitrocellulose in a slot blot apparatus (Schleicher \& Schuell, Inc., Keene, NH). The plasmid DNA coding for GM-CSF was a 5.2-kb HindIII fragment of $\mathrm{B} 1 \mathrm{H} 1$ (ATCC) and the $\beta$-actin was a 2 -kb BamHI fragment (29). The filter was baked $2 \mathrm{~h}$, hybridized with the ${ }^{32} \mathrm{P}$-labeled RNA for 36 $\mathrm{h}$ in $50 \%$ formamide at $42^{\circ} \mathrm{C}$, washed to $0.3 \times \mathrm{SSC}$ at $65^{\circ} \mathrm{C}$, then exposed to Kodak XAR-5 x-ray film.

Half-life. A total of $5 \times 10^{6} \mathrm{MNC}$ were stimulated for $6 \mathrm{~h}$ with PMA $20 \mathrm{ng} / \mathrm{mL}$, PHA $2 \mu \mathrm{g} / \mathrm{mL}$. To block transcription, actinomycin $\mathrm{D}$ was added to the culture medium at a final concentration of $5 \mu \mathrm{g} / \mathrm{mL}$ (30). Cells were harvested at indicated times (0-90 min) and RNA was isolated. The mRNA was detected by Northern hybridization using the B1HI GM-CSF probe. 


\section{RESULTS}

Cord and adult human neutrophils were isolated by FicollHypaque density centrifugation. Using ${ }^{125}$ I-GM-CSF, we determined the equilibrium binding of this ligand to both purified cord and adult human neutrophils. Neutrophils were exposed to iodinated GM-CSF ( $\leq 14000 \mathrm{cpm})$ in the presence or absence of 100 -fold excess of unlabeled ligand for up to $2 \mathrm{~h}$ at $23^{\circ} \mathrm{C}$. As shown in Figure 1, the binding curve and Scatchard analysis of adult neutrophil GM-CSF receptors revealed a single class highaffinity receptor with a $\mathrm{k}_{\mathrm{d}}$ of approximately $44 \mathrm{pM}$. Similarly, in Figure 2, the equilibrium curve and Scatchard analysis demonstrated cord neutrophils to have a single high-affinity GM-CSF receptor and a similar $\mathrm{k}_{\mathrm{d}}$ of $30 \mathrm{pM}$. Using ${ }^{125} \mathrm{I}-\mathrm{GM}-\mathrm{CSF}$ as a ligand, we found a similar number of GM-CSF receptors on cord neutrophils versus adult neutrophils (444 \pm 66.2 versus $658 \pm$ 138 sites/cell, respectively) ( $p=$ NS).

Cord and adult MNC were also isolated by Ficoll-Hypaque density centrifugation. Adult and cord serum were additionally separated. Using an ELISA consisting of a murine antihuman GM-CSF antibody, a rabbit antihuman GM-CSF antibody, and a donkey antirabbit antibody, we measured GM-CSF levels from circulating serum, constitutive supernatants, and stimulated supernatants from cord and adult MNC. Serum levels from both cord and adult MNC cells were both nondetectable $(<10 \mathrm{pg} / \mathrm{mL})$ $(n=4)$. Similarly, constitutive supernatant levels of GM-CSF

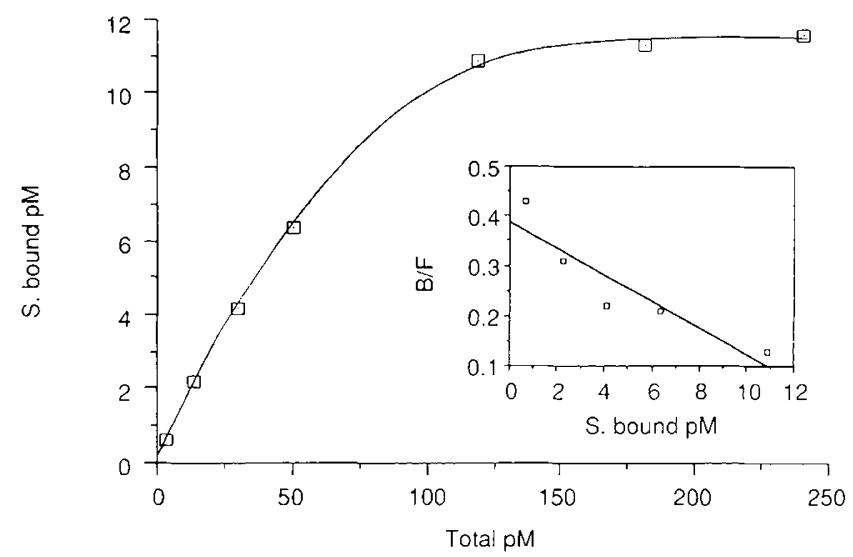

Fig. 1. Specific binding of ${ }^{125}$ I-labeled GM-CSF to neutrophils from adult peripheral blood. The amount of nonspecific binding not blocked by competition with a 100 -fold excess of unlabeled GM-CSF was subtracted from total binding to give the values represented here $(n=2)$. Insert, Scatchard analysis of these equilibrium binding data $\left(k_{d}=44\right.$ pM).

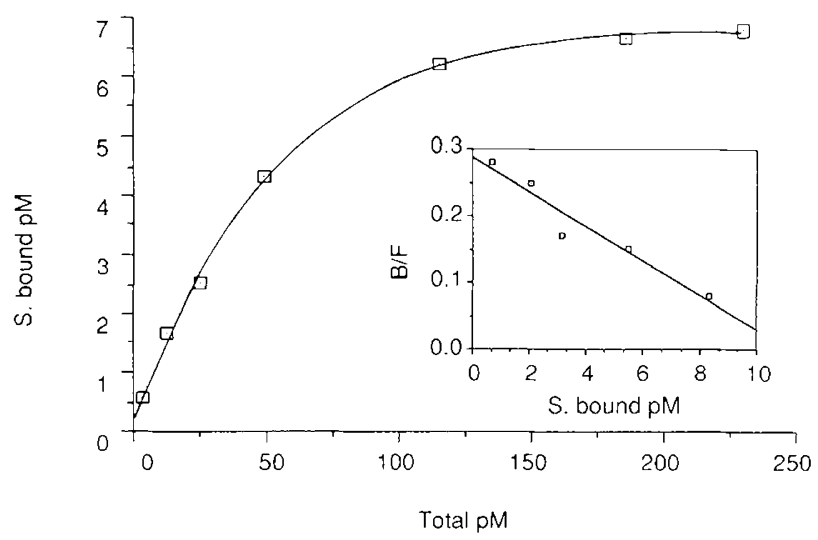

Fig. 2. Specific binding of ${ }^{125}$ I-labeled GM-CSF to neutrophils from cord blood. The amount of nonspecific binding not blocked by competition with a 100 -fold excess of unlabeled GM-CSF was subtracted from total binding to give the values represented here $(n=2)$. Insert. Scatchard analysis of these equilibrium binding data $\left(k_{d}=39 \mathrm{pM}\right)$. from cord and adult MNC also demonstrated nondetectable GM-CSF levels $(<10 \mathrm{pg} / \mathrm{mL})$.

Cord and adult MNC were stimulated with PMA $20 \mathrm{ng} / \mathrm{mL}$ and PHA $2 \mu \mathrm{g} / \mathrm{mL}$ for $0-72 \mathrm{~h}$, and supernatants were analyzed for GM-CSF production. Maximal stimulation from adult MNC occurred within $48-72 \mathrm{~h}$ after stimulation. There appeared to be little difference in GM-CSF production between 24 and $72 \mathrm{~h}$ from stimulated cord MNC. Strikingly, however, there was a marked and significant difference in GM-CSF production between cord and adult stimulated MNC $(4.0 \pm 1.1$ versus $0.57 \pm$ $0.16 \mathrm{ng} / \mathrm{mL}$, adult versus cord; $p<0.02)(72 \mathrm{~h})$.

To determine if decreased GM-CSF production from stimulated cord $\mathrm{MNC}$ was secondary to decreased gene expression, cord and adult MNC unstimulated and stimulated, were evaluated for GM-CSF mRNA expression. Using the GM-CSF probe $\mathrm{B} 1 \mathrm{H} 1$ and a positive and negative control cell line (MoT and A172, respectively), GM-CSF mRNA transcripts were detected by Northern blot hybridization and analyzed by densitometry of autoradiographs. Unstimulated cord and adult MNC GM-CSF mRNA transcripts were barely detectable in both cell populations (time zero) (Fig. 3). However, after $6 \mathrm{~h}$ of stimulation with PHA and PMA, cord MNC expressed significantly decreased GM-CSF mRNA transcripts (Fig. 3). By 24 h however, there was normal expression of cord GM-CSF mRNA transcript (Fig. 3).

To examine the difference between cord and adult GM-CSF mRNA production, we performed nuclear run-on transcription experiments after PHA and PMA treatment. After transcriptional activation, nuclei from untreated and PHA- and PMAtreated cord and adult MNC were isolated and the RNA was hybridized to GM-CSF cDNA. After $6 \mathrm{~h}$ of stimulation, there was no significant difference in transcriptional activation between cord and adult MNC GM-CSF transcription (Fig. 4). We

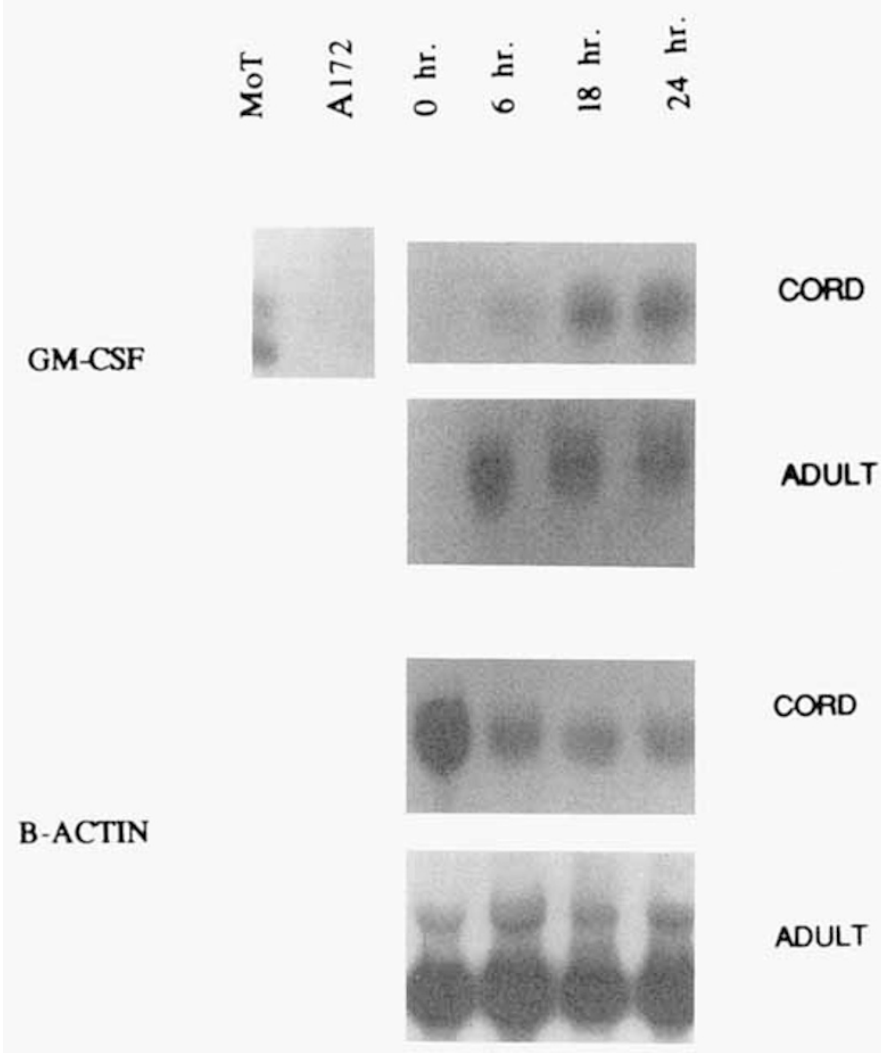

Fig. 3. GM-CSF mRNA levels from unstimulated and stimulated MNC from cord and adult peripheral blood. Cells were isolated and stimulated with PMA $20 \mathrm{ng} / \mathrm{mL}$ and PHA $2 \mu \mathrm{g} / \mathrm{mL}$, and RNA was extracted $(\mathrm{B} 1 \mathrm{H} 1)$. The Northern blot was hybridized with ${ }^{32} \mathrm{P}$-labeled GM-CSF probe. MOT is a human T cell leukemia cell line serving as a positive control for GM-CSF. $A 172$ is a glioblastoma cell line serving as a negative control for GM-CSF $(n=4)$. 


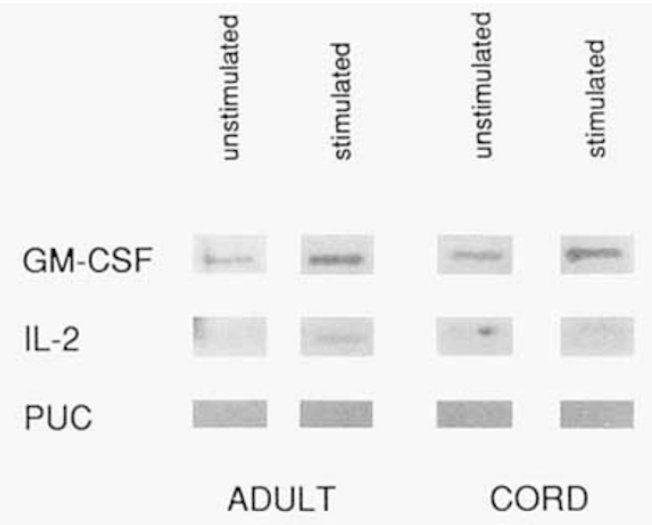

Fig. 4. Nuclear run-on analysis of GM-CSF transcription rates from MNC stimulated with PMA/PHA from both adult and cord peripheral blood. An equal number of counts were hybridized to filters containing the indicated probes $(n=4) P U C$, plasmid controls.
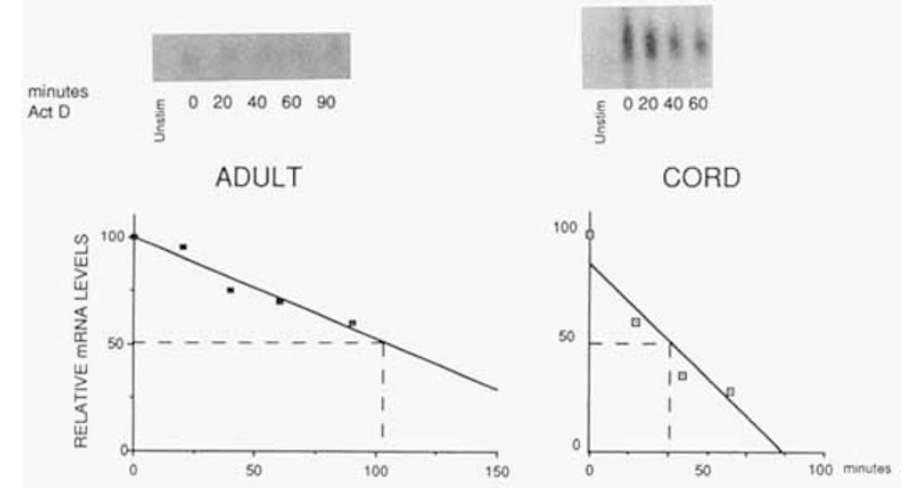

Fig. 5. Northern blot analysis of the half-life of GM-CSF mRNA in stimulated adult and cord MNC. Actinomycin D $(5 \mu \mathrm{g} / \mathrm{mL})$ was added for the indicated times to cells stimulated for $6 \mathrm{~h}$ with $20 \mathrm{ng} / \mathrm{mL}$ PMA and $2 \mu \mathrm{g} / \mathrm{mL}$ PHA. Total cellular RNA was isolated and hybridized to the ${ }^{32}$ P-labeled GM-CSF as described $(n=4)$.

additionally determined the decay of GM-CSF mRNA by inhibiting RNA synthesis with actinomycin D. RNA was extracted from unstimulated and stimulated cord and adult MNC and incubated with actinomycin D $(5 \mu \mathrm{g} / \mathrm{mL})$ and GM-CSF mRNA was analyzed by Northern blot hybridization and quantitated by densitometry. After $6 \mathrm{~h}$ of stimulation with PMA and PHA, the transcriptional decay of GM-CSF mRNA was significantly different between cord MNC and adult MNC. The estimated transcriptional half-life decay of GM-CSF mRNA from cord MNC was approximately $30 \mathrm{~min}$ compared with $100 \mathrm{~min}$ from adult MNC (Fig. 5).

\section{DISCUSSION}

Peripheral neutropenia is a hallmark finding during overwhelming bacterial sepsis in the newborn and is associated with a poor prognosis (31-34). A decrease in total body myeloid progenitor cells (CFU-GM), near-maximal proliferative capacity of myeloid progenitor cells, an accelerated egress of mature neutrophil storage pools from the bone marrow reserve, and accelerated neutrophil use during infection all predispose the human neonate to significant neutropenia during bacterial sepsis (3-7). The true incidence of severe neutrophil storage pool depletion $(<7 \%)$ (PMN + band + metamylocytes) associated with neonatal neutropenia and sepsis is probably less than $15 \%$ $(35,36)$. However, the presence of severe $(<7 \%)$ neutrophil storage pool depletion in neonates with sepsis may not be the only indicator of a poor prognosis in this patient population. Recently, we demonstrated that even a mild or moderate de- crease in the neutrophil storage pool may be associated with an increase in mortality during overwhelming bacterial sepsis (37).

GM-CSF, a hematopoietic growth factor, stimulates bone marrow progenitor cells and influences the growth and proliferation of CFU-GM and CFU-eosinophil, inducing an increase in neutrophils, monocytes, and eosinophils in the peripheral blood (12, 13). GM-CSF has been demonstrated to induce peripheral neutrophilia both secondary to release and egress of neutrophil storage pools cells within the first $24 \mathrm{~h}$ of administration and a sustained peripheral neutrophilia resulting from stimulation of early myeloid progenitor cells and, additionally, has been noted to correct in vitro mature effector neutrophil physiologic dysfunction (38-40). We have recently demonstrated that human GM-CSF also primes and stimulates neonatal neutrophils for enhanced functional activity $(20,21)$. Broxmeyer et al. (41) have also demonstrated that term cord blood myeloid progenitor cells, i.e. CFU-GM, respond similarly to adult bone marrow CFUGM during in vitro human GM-CSF stimulation. Laver et al. (42), using a bioassay, have even demonstrated increased circulating plasma levels of GM-CSF from term umbilical cord blood compared with normal circulating adult plasma levels.

Our study was designed to evaluate the affinity and number of GM-CSF receptors on mature effector neutrophils from both cord and adult cells and to additionally determine constitutive and stimulated GM-CSF production from both cord and adult MNC. Using ${ }^{125} \mathrm{I}-\mathrm{GM}-\mathrm{CSF}$ as a ligand, we were able to demonstrate similar binding characteristics and a single class affinity receptor for GM-CSF. Additionally, we have demonstrated that the number of GM-CSF receptors on peripheral mature effector neutrophils is similar from both cord and adult peripheral blood. Our affinity studies and the number of GM-CSF receptors on adult neutrophils are similar to those found by a number of other investigators $(43,44)$. It remains to be seen, however, whether the number and/or affinity of GM-CSF receptors is similar or different between cord and adult bone marrow myeloid progenitor cells.

GM-CSF production, however, was markedly different from activated cord MNC compared with activated adult MNC. During in vitro stimulation with PHA and PMA, activated cord MNC produced almost $16 \%$ of GM-CSF compared with similar activated adult MNC. This is in stark contrast to constitutive GM-CSF levels from supernatants of unstimulated cord and adult MNC and circulating serum levels, which were barely detectable using our ELISA. This differs from the study by Laver et al. (42), who demonstrated increased circulating plasma levels of GM-CSF in cord blood compared to adult blood. The difference in our constitutive levels compared with Laver's are probably 2 -fold. In the study by Laver et al. (42), they chose to measure plasma GM-CSF levels by using a bioassay (human cell line TALL 101). The growth in this bioassay, however, may be influenced by other growth factors and may lead to different conclusions. In fact, as reported in Laver's study (42), when the authors coincubated with MAb to GM-CSF (anti-GM-CSF), they demonstrated an $11 \%$ residual bioactivity from their cord samples, probably secondary to the presence of other growth factors. Additionally, the difference in the results from our stimulated mononuclear studies may include the lack of contribution of endothelial cells or fibroblasts to GM-CSF production. Therefore, total GM-CSF production could be estimated from this study. Lastly, this study did not evaluate whether the decrease in GM-CSF production from cord MNC occurs secondary to a decrease per cell or a decrease in a subpopulation of GM-CSF producing MNC.

Our data additionally suggest that decreased GM-CSF production from activated cord MNC compared with adults may in part be secondary to decreased GM-CSF mRNA expression. After a 6-h incubation with PHA and PMA, cord MNC expressed significantly reduced GM-CSF mRNA compared with similarly stimulated adult MNC. In an attempt to elucidate the mechanism for decreased GM-CSF mRNA expression after $6 \mathrm{~h}$ of stimulation 
from cord MNC compared with adults, we studied transcriptional activation with nuclear run-on studies and transcriptional decay with actinomycin $\mathrm{D}$ inhibition studies. The nuclear runon studies suggested no difference in transcriptional activation between cord and adult MNC relative to GM-CSF expression. However, our actinomycin D half-life studies suggested decreased stabilization of GM-CSF mRNA from 6-h stimulated cord MNC compared with adult cells. This reduced stabilization of GMCSF mRNA from stimulated cord MNC may account in part for the decreased amount of GM-CSF mRNA and GM-CSF production during states of activation.

Our data suggesting decreased GM-CSF production and decreased GM-CSF mRNA expression from cord MNC are consistent with that of other investigations evaluating the production and activation of other cytokines from newborn MNC. Specifically, tumor necrosis factor- $\alpha$ appears to be decreased from stimulated neonatal MNC and may be secondary to decreased tumor necrosis factor- $\alpha$ mRNA expression $(45,46)$. Similarly, recent studies have demonstrated decreased $\gamma$-interferon production and reduced $\gamma$-interferon mRNA from stimulated human neonatal $\mathrm{MNC}(47,48)$.

The control of GM-CSF production by adult MNC is secondary to a series of transcriptional and posttranscriptional regulatory processes. Nimer et al. (49) demonstrated that the genomic region responsible for the expression of GM-CSF mRNA from activated adult $T$ lymphocytes probably occurs within a $90-b p$ region containing 53 nucleotides upstream and 37 nucleotides downstream from the start site of GM-CSF transcription. Using the technique of DNAase I footprinting, Gasson et al. (50) demonstrated that nuclear extracts from MLA-144 cells stimulated with PHA and TPA were bound to specific regions from this GM-CSF promoter region. Additionally, the GM-CSF gene has been demonstrated to be AT-rich in the $3^{\prime}$ untranslated segment, a finding similar to that in other cellular genes including c-myc and c-fos. This AT-rich region has been shown to have a destabilizing effect on mRNA production by recombinant constructs and, therefore, may play an important role in GM-CSF mRNA decay (51). Further investigations are planned to examine the difference between cord and adult GM-CSF mRNA stability and GM-CSF gene transcription from activated MNC.

During states of increased demand, quantitative deficiencies in neonatal myeloid progenitor activity and decreased availability of mature effector neutrophils have predisposed the newborn to a high mortality rate during overwhelming bacterial sepsis. Previous prospective and randomized trials using adult PMN transfusions versus standard supportive care have suggested a possible therapeutic benefit of using readily available and functionally active adult granulocytes to reduce the morbidity and mortality associated with bacterial sepsis in the newborn $(37,52-54)$. The benefits of granulocyte transfusions in septic neutropenic neonates must be carefully evaluated against the possible side effects associated with such transfusions, and additional questions still remain regarding the future role of such therapy. Therefore, other therapeutic measures designed to maintain high circulating neutrophil counts during overwhelming bacterial sepsis in the newborn must be explored. Recently, we demonstrated that prophylactic and prolonged G-CSF administration to newborn rats was protective in reducing the high mortality rate associated with experimental group B streptococcal sepsis (55). Additionally, murine GM-CSF has been noted to enhance neonatal rat myelopoiesis and reduce the mortality rate associated with experimental bacterial infection in the newborn rat $(22,23)$.

In summary, this study has demonstrated that stimulated cord MNC manifest decreased GM-CSF production and GM-CSF mRNA expression compared with similar stimulated adult MNC. Additionally, circulating GM-CSF serum levels and constitutive GM-CSF supernatants from unstimulated MNC are barely detectable from both cord and adults. The affinity and binding and the number of GM-CSF receptors on cord mature neutrophil effector cells are similar to those demonstrated in similar populations of adult cells. The decrease in GM-CSF production and gene expression may be secondary to decreased stability of cord mononuclear GM-CSF mRNA. Reduced stability of GM-CSF mRNA from cord MNC may account, in part, for altered host defense that has been previously demonstrated in the newborn. The demonstration of normal levels of GM-CSF receptors on peripheral cord effector cells, the in vitro functional activation of circulating cord mature neutrophil effector cells by GM-CSF, and the previous demonstration that murine GM-CSF modulates neonatal rat host defense against experimental bacterial infection all suggest the possible future role of exogenous rhGM-CSF to modulate neonatal human host defense.

\section{REFERENCES}

1. Christensen RD 1989 Hematopoiesis in the fetus and neonate. Pediatr Res 26:531-535

2. Cairo MS 1989 Neonatal neutrophil host defense. Am J Dis Child 143:40-46

3. Christensen RD, Rothstein G 1984 Pre and postnatal development of granulocyte stem cells (CFUc) in the rat. Pediatr Res 18:599-602

4. Erdman SH, Christensen RD, Bradley PP, Rothstein G 1982 The supply and release of storage neutrophils. A developmental study. Biol Neonate 41:132137

5. Christensen RD, Hill HR, Rothstein G 1983 Granulocytic stem cell (CFU-C) proliferation in experimental group B streptococcal sepsis. Pediatr Res 17:278-280

6. Christensen RD, MacFarlane JL, Taylor NL, Hill HR, Rothstein G 1982 Blood and marrow neutrophils during experimental group $B$ streptococcal infection: quantification of the stem cell, proliferative, storage and circulating pools. Pediatr Res 16:549-553

7. Christensen RD, Shigeoka AO, Hill HR, Rothstein G 1980 Circulating and storage neutrophil changes in experimental type II group B streptococcal sepsis. Pediatr Res 14:806-808

8. Cannistra SA, Griffin JD 1988 Regulation of the production and function of granulocytes and monocytes. Semin Hematol 25:173-178

9. Sieff CA 1987 Hematopoietic growth factors. J Clin Invest 79:1549-1557

10. Clark SC. Kamen R 1987 The human hematopoietic colony-stimulating factors. Science 236:1229-1237

11. Nathan DG 1990 Regulation of hematopoiesis. Pediatr Res 27:423-431

12. Gasson JC, Weisbart RH, Kaufman SE, Clark SC, Hewick RM, Wong GG, Golde DW 1984 Purified human granulocyte-macrophage colony stimulating factor: direct action on neutrophils. Science 226:1339-1342

13. Metcalf D, Begley CG, Johnson GR, Nicola NA, Vadas M, Lopez A, Williamson DJ, Wang EA, Wang CG, Clark SC 1986 Biologic properties in vitro of a recombinant human granulocyte-macrophage colony-stimulating factor identification as CSF alpha. Blood 67:37-45

14. Grabstein KH, Urdal DL, Tushinski RJ, Mochizuki DY. Price VL, Cantrell MA, Gillis S, Conlon PJ 1986 Induction of macrophage tumoricidal activity by granulocyte-macrophage colony-stimulating factor. Science 232:506-508

15. Weisbart RH, Golde DW, Clark SC, Wong GG, Gasson JC 1985 Human granulocyte-macrophage colony-stimulating factor is a neutrophil activator Nature 314:361-363

16. Weisbart RH, Gold DW, Gasson JC 1986 Biosynthetic human GM-CSF modulates the number and affinity of neutrophil f-met-Leu-Phe receptors. J Immunol 137:3584-3587

17. Fleischmann J, Golde DW, Weisbart RH, Gasson JC 1986 Granulocytemacrophage colony-stimulating factor enhances phagocytosis of bacteria by human neutrophils. Blood 68:708-711

18. Weisbart RH, Kwan L, Golde DW, Gasson JC 1987 Human GM-CSF primes neutrophils for enhanced oxidative metabolism in response to the major physiological chemoattractants. Blood 69:18-21

19. Groopman JE, Molina JM, Scadden DT 1989 Hematopoietic growth factors Biology and clinical applications. N Engl J Med 321:1449-1459

20. Cairo MS, van de Ven C, Toy C, Mauss D, Sender L 1989 Recombinant human granulocyte-macrophage colony-stimulating factor primes neonatal granulocytes for enhanced oxidative metabolism and chemotaxis. Pediat Res 26:395-399

21. Cairo MS, van de Ven C. Mauss D, Kommareddy S, Norris K, Sheikh K, Modanlou H 1991 Modulation of neonatal rat myeloid kinetics resulting in peripheral neutrophilia by single pulse administration of $\mathrm{Rh}$ granulocytemacrophage colony-stimulating factor and $\mathrm{Rh}$ granulocyte colony-stimulating factor. Biol Neonate 59:13-21

22. Cairo MS. Mauss D. Plunkett JM. Gillis S, van de Ven C 1991 Modulation of neonatal myelopoiesis in newborn rats after 7 days administration of either granulocyte-monocyte colony stimulating factor or interleukin-3. Pediatr Res 29:504-509

23. Frenck RW, Sarman G. Harper TE, Buescher ES 1990 The ability of recombinant murine granulocyte-macrophage colony-stimulating factor to protect neonatal rats from septic death due to Staphlococcus aureus. J Infect Dis 162:109-114

24. Gasson JC, Kaufman SE, Weisbart RH, Tomonaga M 1986 High-affinity binding of GM-CSF to normal and leukemic human myeloid cells. Proc Natl Acad Sci USA 85:669-673

25. Munson PJ, Rodbard DR 1980 Ligand: a versatile computerized approach for characterization of ligand-binding systems. Anal Biochem 107:220-239 
26. Cebon J, Dempsey P, Fox R, Kannourakis G, Bonnem E, Burgess A, Mortsyn G 1988 Pharmacokinetics of human GM-CSF using a sensitive immunoassay. Blood 72:1340-1347

27. Chomczynski P, Sacchi N 1987 Single-step method of RNA isolation by acid guanidinium thiocyanate-phenol-chloroform extraction. Anal Biochem 162:156-159

28. Satterthwaite AB, Borson R, Tenen DG 1990 Regulation of the gene for CD34, a human hematopoietic stem cell antigen, in KG-1 cells. Blood 75:22992304

29. Gunning P, Ponte P, Okayama H, Engel J, Blau H, Kedes L 1983 Isolation and characterization of full-length cDNA clones for human alpha-, beta-, and gamma-actin mRNAs: skeletal but not cytoplasmic acins have an aminoterminal cysteine that is subsequently removed. Mol Cell Biol 3:787-795

30. Schuler GD, Cole MD 1988 GM-CSF and oncogene mRNA stabilities are independently regulated in trans in a mouse monocytic tumor. Cell 55:1115 1122

31. Akenzua GI, Hui YT, Milner R, Zipursky A 1974 Neutrophil and band counts in the diagnosis of neonatal infection. Pediatr 54:38-42

32. Zipursky A, Palko J, Milner R, Akenzua GI 1976 The hematology of bacterial infections in premature infants. Pediatrics 57:839--853

33. Manroe BL, Rosenfeld CR, Weinberg AG, Browne R 1977 The differential leukocyte count in the assessment and outcome of early-onset neonatal group B streptococcal disease. J Pediatr 91:632-637

34. Manroe BL, Weinberg AG, Rosenfeld CR, Browne R 1979 The neonatal blood count in health and disease. I. Reference values for neutrophilic cells. J Pediatr 95:89-98

35. Cairo MS 1989 Neutrophil storage pool depletion in neonates with sepsis. J Pediatr 116:1064

36. Engle WA, McGuire WA, Schreiner RL, Yu PL 1988 Neutrophil storage poo depletion in neonates with sepsis and neutropenia. J Pediatr 113:747-749

37. Cairo MS 1989 Neutrophil transfusions in treatment of neonatal sepsis. Am J Pediatr Hematol Oncol 11:227-234

38. Nienhuis AW, Donahue RE, Karlsson S, Clark SC, Agricola B, Antinoff N, Pierce JE, Turner P, Anderson WF, Nathan DG 1987 Recombinant human granulocyte-macrophage colony-stimulating factor (GM-CSF) shortens the period of neutropenia after autologous bone marrow transplantation in a primate model. J Clin Invest 80:573-577

39. Groopman JE, Mitsuyasu RT, DeLeo MJ, Oette DH, Golde DW 1987 Effect of recombinant human granulocyte-macrophage colony-stimulating factor on myelopoiesis in the acquired immunodeficiency syndrome. N Engl J Med 317:593-598

40. Baldwin GC, Gasson JC, Quan SG, Fleischmann J, Weisbart R, Oette D, Mitsuyasu RT, Golde DW 1988 Granulocyte-macrophage colony-stimulating factor enhances neutrophil function in acquired immunodeficiency syndrome patients. Proc Natl Acad Sci USA 85:2763-2766

41. Broxmeyer HE, Douglas GW, Hangoc G, Cooper S, Bard J, English D, Amy M, Thomas L, Boyse EA 1989 Human umbilical cord blood as a potential source of transplantable hematopoietic stem/progenitor cells. Proc Natl Acad Sci USA 86:3828-3832

42. Laver J, Duncan E, Abboud M, Gasparetto C, Sahdev I, Warren D, Bussel J, Auld P, O'Reilly RJ, Moore MAS 1990 High levels of granulocyte and granulocyte-macrophage colony-stimulating factors in cord blood of normal full-term neonates. J Pediatr 116:627-632

43. Park LS, Waldron PE, Friend D, Sassenfeld HM, Price V, Anderson D, Cosman D, Andrews RG, Bernstein ID. Urdal DL 1989 Interleukin-3. GM-CSF and G-CSF receptor expression on cell lines and primary leukemia cells: receptor heterogeneity and relationship to growth factor responsiveness. Blood 74:5665

44. Cannistra SA, Groshek P, Garlick R, Miller J, Griffin JD 1990 Regulation of surface expression of the granulocyte/macrophage colony-stimulating factor receptor in normal human myeloid cells. Proc Natl Acad Sci USA 87:93-97

45. English K Burchett SK, English JD, Ammann AJ, Wara DW, Wilson CB 1988 Production of lymphotoxin and tumor necrosis factor by human neonatal mononuclear cells. Pediatr Res 24:717-722

46. Weatherstone KB, Rich EA 1989 Tumor necrosis factor/cachectin and interleukin-1 secretion by cord blood monocytes from premature and term neonates. Pediatr Res 25:342-346

47. Wilson CB, Westall J, Johnston L, Lewis DB, Dower SK, Alpert AR 1986 Decreased production of interferon-gamma by human neonatal cells. J Clin Invest 77:860-867

48. Lewis DB, Larsen A, Wilson CB 1986 Reduced interferon-gamma mRNA levels in human neonates. Evidence for an intrinsic $\Upsilon$ cell deficiency independent of other genes involved in T cell activation. J Exp Med 163:10181023

49. Nimer SD, Morita EA, Martis MJ, Wachsman W, Gasson JC 1988 Characterization of the human GM-CSF promoter region by genetic analysis: correlation with DNase I footprinting. Mol Cell Biol 8:1979-1984

50. Gasson JC, Fraser JK, Nimer SD 1990 Human granulocyte-macrophage colony-stimulating factor (GM-CSF): regulation of expression. Prog Clin Biol Res 338:27-34

51. Shaw $G$, Kamen R 1986 A conserved AU sequence from the 3' untranslated region of GM-CSF mRNA mediates selective mRNA degradation. Cell 46:659-667

52. Cairo MS, Rucker $R$, Bennetts GA, Hicks D, Worcester $C$, Amlie $R$, Johnson $\mathrm{S}$, Katz J 1984 Improved survival of newborns receiving leukocyte transfusion for sepsis. Pediatrics 74:887-892

53. Cairo MS, Worcester C, Rucker R, Bennetts GA, Amlie R, Perkin R, Anas N, Hicks D 1987 Role of circulating complement and polymorphonuclear leukocyte transfusion in treatment and outcome in critically ill neonates with sepsis. J Pediatr 1 10:935-941

54. Christensen RD, Rothstein G, Anstall HB Bybee B 1982 Granulocyte transfusions in neonates with bacterial infection, neutropenia and depletion of mature marrow neutrophils. Pediatrics $70: 1-6$

55. Cairo MS, Plunkett JM, Mauss D, van de Ven C 1990 Seven-day administration of recombinant human granulocyte colony-stimulating factor to newborn rats: modulation of neonatal neutrophilia, myelopoiesis, and group B streptococcus sepsis. Blood 76:1788-1794 